\title{
CD25 Expression is Associated with Autoimmunity in Patients with CLL
}

\author{
Hacer Berna AFACAN OZTURK ${ }^{1}$, Abdulkerim YILDIZ ${ }^{1}$, Murat ALBAYRAK ${ }^{1}$, \\ Cigdem PALA ${ }^{1}$, Senem MARAL ${ }^{1}$, Mesude FALAY ${ }^{2}$ \\ ${ }^{1}$ University of Health Sciences, Diskapi Yildirim Beyazit Training and Research Hospital, \\ Department of Hematology \\ ${ }^{2}$ University of Health Sciences, Numune Training and Research Hospital, \\ Department of Hematology, Ankara, TURKEY
}

\begin{abstract}
It has been shown that CD25 is expressed more in Chronic Lymphocytic Leukemia (CLL) cases. However, there is conflicting data as to its prognostic significance. The aim of this study was to examine the prognostic significance of CD25 in cases in our centre. A retrospective examination was made of hospital records and flow cytometry results at the time of diagnosis of 160 patients diagnosed with CLL in our clinic between June 2009 and April 2018. An analysis of cases with and without CD25 cell surface expression for overall survival and time to treatment revealed no significant difference between the two groups in respect of both parameters (Graphic $1, p>0.05$ and Graphic 2, p> 0.05). Autoimmune cytopenia was determined to be significantly more common in the CD25-negative group. CD25 was seen to have no prognostic significance in CLL. However, a significantly increased rate of autoimmune cytopenia was determined in cases with CD25 negativity. Since this study is the first to demonstrate the relationship between CD25 expression and autoimmune cytopenia in patients with CLL, it may be of guidance for future studies on the same subject and may draw the attention of clinicians to this in clinical practice.
\end{abstract}

Keywords: CD25, Chronic Lymphocytic Leukemia, Autoimmunity, Flow cytometry

ÖZET

\section{KLL'li Hastalarda CD25 Ekspresyonu Otoimmünite ile İlişkilidir}

CD25'in KLL (Kronik Lenfositik Lösemi) vakalarında daha fazla eksprese edildiği gösterilmiştir. Ancak prognostik bir öneminin olup olmadığı ile ilgili çelişkili çalışmalar mevcuttur. Biz de kendi vakalarımızda CD25'in prognostik önemine bakmak istedik. Haziran 2009 ve Nisan 2018 tarihleri arasında kliniğimizde KLL tanısı almış 160 hastanın retrospektif olarak hastane kayıtları ve tanı anındaki akım sitometri sonuçları incelendi. CD25 hücre yüzeyi ekspresyonu olan ve olmayan olgular, overall survival ve time to treatment için değerlendirildiğinde her ikisi içinde iki grup arasında istatistiksel olarak anlamlı düzeyde fark olmadığı tespit edilmiştir (Grafik 1, p> 0.05 ve Grafik 2, p> 0.05). Ancak CD25 negatif olan grupta otoimminositopeni, istatistiksel olarak daha fazla görüldü. CD25'in KLL'de prognostik bir önemi olmadığını gösterdik. Ancak CD25 negatifliği ile otoimmunsitopenilerin sıklığının istatistiksel olarak arttığını gördük. Çalışmamız CD25 ekspresyonunun KLL hastalarında otoimminositopeni ile ilişsisini gösteren ilk çalışma olduğu için bundan sonra yapılacak olan çalışmalara ışık tutabilir ve klinisyenlerin klinik pratikte bu konuya dikkatlerini çekebilir.

Anahtar Kelimeler: CD25, Kronik Lenfositik Lösemi, Otoimmünite, Akım sitometri

ORCIDS: Hacer Berna Afacan Öztürk: 0000-0001-9386-7604 Murat Albayrak: 0000-0003-4025-741X Mesude Falay: 0000-0001-7846-3476

UHOD Number: 3 Volume: 29 Year: 2019
Abdulkerim Yildiz: 0000-0002-9596-4042

Cigdem Pala: 0000-0002-2455-0969 Senem Maral: 0000-0003-4766-1861 


\section{INTRODUCTION}

Chronic Lymphocytic Leukemia (CLL) is the most common leukemia type in adults in western countries and is characterized by an increased number of neoplastic B lymphocytes with mature appearance in tissues with a lymphoid component, such as peripheral blood, bone marrow, lymph nodes, spleen, and liver. ${ }^{1-3}$ Diagnosis requires that the number of monoclonal B lymphocytes exceeds 5000 per $\mathrm{mm}^{3}$ in peripheral blood, and these lymphocytes should carry immunophenotypic (CD5+, CD19+, CD20+, CD23+, surface membrane immunoglobulins) features specific for CLL in flow cytometry. ${ }^{3}$ Autoimmune disorders may commonly occur during the course of CLL, the most common of which is autoimmune hemolytic anemia (AIHA) in which antibodies are formed directly against red blood cell antigens. This is followed by autoimmune thrombocytopenia (AITP), rarely pure red cell aplasia (PRCA), and very rarely autoimmune agranulocytosis (AIG) ${ }^{4}$ Of these, AIHA is the most important (7-10\%) followed at lower rates by AITP $(1-5 \%)$ and PRCA $(<1 \%)$. $^{5-7}$

CD25 antigen is the interleukin-2 (IL-2) receptor alpha chain and is expressed more than normal B lymphocytes in 35-50\% of CLL cases. ${ }^{8}$ CD25 expression has also been associated with shorter treatment-free survival and a higher rate of disease progression. ${ }^{9}$ Cell expression of CD25 antigen and increased serum levels of soluble CD25 have been shown to be a predictor of poor outcome in B lineage acute lymphoblastic leukemia ${ }^{10}$ and diffuse large B-cell lymphoma. ${ }^{11}$

Several studies have provided conflicting data about the prognostic significance of CD expression in CLL. Two reports published in recent years have indicated that patients with cells expressing CD25 had a worse prognosis than those with CD25-negative cells. ${ }^{9,12}$

Nevertheless, two subsequent reports indicated that CD25 positivity was a good prognostic sign for CLL. ${ }^{13,14}$ A more recent retrospective study reported that $\mathrm{CD} 25$ expression had no prognostic role nor did it have any correlation with time to first treatment or overall survival. ${ }^{8}$

The aim of this study was to investigate the prog- nostic significance of CD25 in CLL. To the best of our knowledge, this is the first study to demonstrate the relationship of CD25 expression with autoimmunity in CLL and can be therefore considered of value for the guidance of future large-scale studies and literature in this field.

\section{PATIENTS AND METHODS}

\section{Patients and Samples}

A retrospective review was made of the medical records of 160 CLL patients ( 85 females, 75 males) aged 37- 89 years (mean age $64.26 \pm 11.79$ ) who were diagnosed according to the National Cancer Institute-sponsored Working Group guidelines for chronic lymphocytic leukemia (NCI-WG) criteria [1] between June 2009 and April 2018 by Training and Research Hospital, Department of Hematology. Complete blood count was examined and peripheral blood or bone marrow smears were obtained for morphological evaluation under MayGrunwald-Giemsa staining. Peripheral blood or bone marrow was withdrawn into 4-mL K3EDTA tubes (BD Vacutainer ${ }^{\circledR}, \mathrm{CA}, \mathrm{USA}$ ) as an anticoagulant and processed within 2 hours after collection.

\section{Flow Cytometry}

To perform immunophenotyping with flow cytometric study, fresh peripheral blood/bone marrow samples were taken into $4 \mathrm{~mL} \mathrm{K3}$ EDTA containing tubes (BD Vacutainer $\left.{ }^{\circledR}, \mathrm{CA}, \mathrm{USA}\right)$, and studied as soon as possible on the day of sampling. Cells in suspension $\left(2 \times 10^{6}\right.$ cells in $50-100 \mu \mathrm{L}$ per tube) obtained from the peripheral blood/bone marrow samples were stained with monoclonal antibodies (MoAb) against cell surface markers using a stain-lyse-and-then-wash direct immunofluorescence technique, as described elsewhere. ${ }^{15}$ The MoAbs used for labeling with flow cytometry were obtained from Beckman Coulter, USA and included CD45 APC, CD79b ECD, CD3PE, CD5PC5, CD10 ECD, FITC, CD11c FITC, CD19 PE, CD19 ECD, CD20 ECD, CD22 PC5, CD23 FITC, CD25 APC, CD38 PC5, CD103 PE, FMC7 FITC, CD43 APC, Kappa FITC, and Lambda PE. The following panel of 4-5 color combinations of MoAbs 
was used in all cases: Fluorescein Isothiocyanate (FITC), Phycoerythrin (PE), Phycoerythrin-Cyanine 5 (PC5), Phycoerythrin-Texas Red (ECD), and Allophycocyanin (APC). The completion of sample staining was immediately followed by data acquisition with a Beckman Coulter (BC) flow cytometer (Navios, BC, USA) and Kalusa software (BC, USA). In each sample, data from at least $10 \mathrm{x}$ 104 events per tube were obtained. Briefly CD19+ $\mathrm{B}$ cells were picked (at least 2000 events according to the threshold of the isotypic control). The data file utilized the conventional gating strategies (forward and side light scatter and the pattern of CD19 expression). The computer software Kalusa (BC) was used to determine a positive result with any antibody using a cutoff limit of $30 \%$ of lymphoid cells, as recommended by the British Committee for Standards in Haematology (BCSH) guideline. ${ }^{16}$ Matatutes scoring was accepted to indicate cell surface expression of $30 \%$ or greater. Instrument alignment was checked on a daily basis, with the help of an alignment control bead (Flow-Check, Beckman Coulter). A fluorescence standard bead (Flow-Set, Beckman Coulter) was used on a daily basis to ensure instrument sensitivity, which was kept within $1 \%$. Cell count accuracy and precision were checked with the international quality controls purchased from the United Kingdom National External Quality Assessment Scheme (UK NEQASLI, Sheffield, UK) (z score range -2.0 - 2.0). LPD was diagnosed using the WHO classification based on clinical information in addition to morphological, immunophenotypic, and genetic criteria. All cases were classified using the revised Matatutes score system ${ }^{17}$, which utilizes the immunophenotypic analysis of five membrane markers (CD5, CD23, FMC7, surface Ig, CD79b).

\section{Ethical approval and informed consent}

All procedures performed in studies involving human participants were in accordance with the ethical standards of the institutional and/or national research committee and with the 1964 Helsinki Declaration and its later amendments or comparable ethical standards. As a standard of care/action of Training and Research Hospital, the patient records confirmed that all the study patients gave informed consent at the time of hospitalization and before the administration of chemotherapy and other relevant diagnostic/therapeutic standards of care.

\section{Statistical Analysis}

SPSS for Windows, version 24 (SPSS Inc., Chicago, IL, USA) was used for all statistical analyses. Descriptive statistics included the number of cases and percentages. Demographic, clinical, or laboratory variables were compared using the MannWhitney test or Chi-square test. The Kaplan-Meier method was used to determine survival curves and the Log-rank test to compare survival. Statistical significance was set at $\mathrm{p}<0.05$.

\section{RESULTS}

During the study period of 2009-2018, circulating mononuclear cells were obtained from 160 CLL patients at the time of diagnosis and examined for CD25 antigen expression. Of the 160 patients, 114 (71.3\%) were found to be positive for CD25. The baseline clinical and laboratory patient characteristics are summarized and presented in Table 1.

There were no significant differences between patients with and without CD25 cell surface expression in respect of mean age at diagnosis, mean lymphocyte count, mean hemoglobin level, mean thrombocyte count, beta 2 microglobulin level, LDH level, time to treatment (months), last followup duration (months), albumin, lymphadenopathy, splenomegaly, stages according to the Binet staging, CD38 positivity, status of secondary tumor development, and deletion 17P positivity ( $\mathrm{p}>0.05$ ).

Of 160 patients, 12 (7.5\%) had autoimmune cytopenia; of those, 8 had AIHA, 3 AITP, and 1 both AIHA and AITP. There was a significant correlation between CD25 surface expression state and autoimmune cytopenia status $\left(\chi^{2}=5.543 ; \mathrm{p}=0.019\right)$. In $7(15.2 \%)$ patients with autoimmune cytopenia, the CD25 level was negative whereas those without $(n=109,95.6 \%)$ had a positive CD25 level $(\mathrm{p}=$ $0.019)$.

The two groups with and without CD25 cell surface expression were not significantly different in respect of both overall survival (Log Rank (Mantel-Cox) test, Graphic 1, p>0.05) and time to treat- 


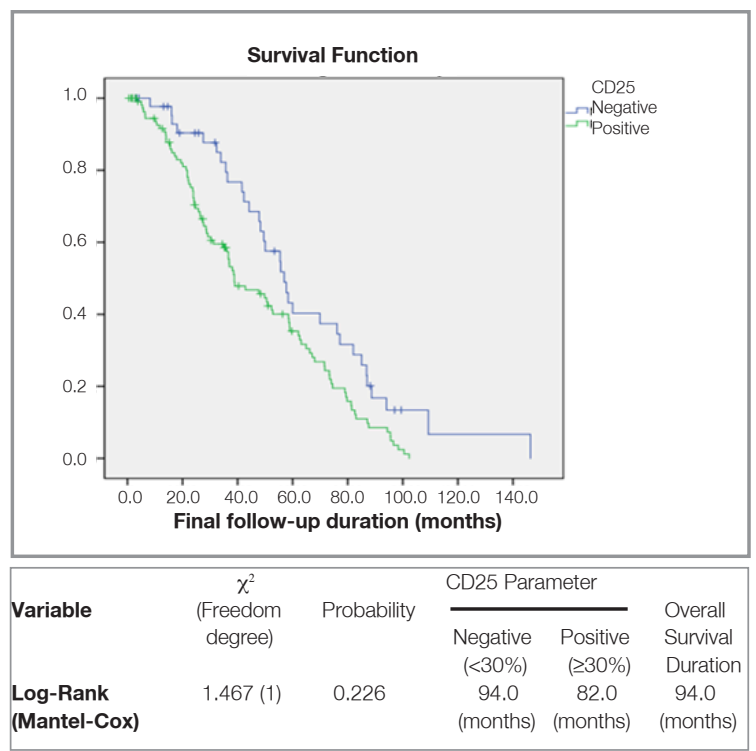

Graphic 1. Distribution of survival function based on cases with and without CD25 cell surface expression

ment (Log Rank (Mantel-Cox) test, Graphic 2, p> $0.05)$.

\section{DISCUSSION}

In this study, an evaluation was made of the incidence of the expression of CD25 antigen (IL-2 receptor alpha chain) and its prognostic significance in CLL patients in our clinic.

In previous years, Tefferi A. et al and Hjalmar V. et al showed that CLL patients whose cells express nCD25 had a worse prognosis than those with CD25-negative cells. ${ }^{9,12}$ Tefferi A. et al demonstrated that CD25 positivity was associated with increased likelihood of disease progression and shortened time to treatment in 62 CLL patients. ${ }^{9}$ Hjalmar V. et al, in a study on 68 CLL patients, found CD25 to be correlated to a shorter time to treatment. ${ }^{12}$ Shvidel L. et al studied 281 CLL patients retrospectively and reported that CD25 had no prognostic significance. ${ }^{8}$ According to these studies, the impact of $\mathrm{CD} 25$ positivity on prognosis is still unclear. In the current study, 160 patients diagnosed with CLL were retrospectively analyzed and no statistically significant differences were found between CD25-positive and CD25-negative patients in respect of overall survival and time to

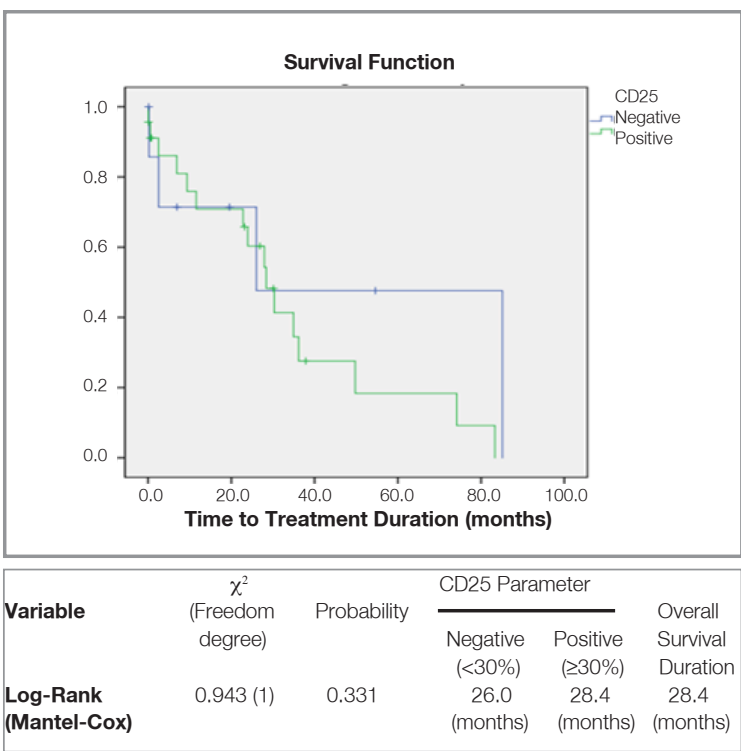

Graphic 2. Distribution of survival function of the time to treatment durations based on cases with and without CD25 cell surface expression

treatment. However, autoimmune cytopenia was significantly more common in the CD-25 negative group than in the CD25-positive group $(\mathrm{p}=0.019)$.

There are a few studies reported association of CD25 expression and autoimmunity. It has recently been reported that FOXP3 + CD4 + T cells with low $\mathrm{CD} 25$ expression were increased in the blood of patients with systemic lupus erythematosus (SLE) ${ }^{18,19}$; subsequently, this observation was extended to patients with multiple sclerosis ${ }^{20}$ and rheumatoid arthritis. ${ }^{21}$ However, the frequency of CD25low FOXP3 + T cells has been shown to be correlated to dsDNA antibody levels ${ }^{18,22}$, suggesting that these cells may be directly responsible or biomarkers of autoimmunity in such patients. Similarly, In a study by Zhang B. et al, it was demonstrated that the number of the CD4-positive CD25-negative $T$ cells was significantly increased compared to the CD4-positive CD25-positive T cells among patients with newly diagnosed systemic lupus erythematosus. They suggested that CD25 negativity may be important for autoimmunity. ${ }^{22}$ In another research, the rate of IL-2R (CD25) expression of soluble-IL-2R and CD4 positive T cells, compared to a control group, was reduced in the sera of euthyroid women with a history of autoimmune hyper-hypothyroidism in first- and 
second-degree relatives who were at increased risk of developing thyroid autoimmunity. ${ }^{23}$ Else, there have been few cases of congenital CD25 deficiency recently reported. Those patients had CD 25 deficiency together with an IPEX-like syndrome and associated with autoimmune cytopenias, and autoimmune enteropathy. ${ }^{24}$

On the other hand, in an animal experiment on rats immunized with anti-CD25 antibodies, it was shown that AIHA incidence increased more than $90 \%$ with a reduced number of CD25-positive cells, suggesting that the suppressive properties of T-regulatory CD25-positive cells have a critical role in the development of autoimmune disorders. ${ }^{25}$ Based on this assumption, it can be suggested that CD surface marker may be operational in statistically more prevalent autoimmune cytopenias in CD25-negative CLL patients.

All these previous studies demonstrated an association of CD25 with autoimmunity. However, they analyzed CD25 expression on the surface of $\mathrm{T}$ cells. In the current study, we showed association of reduced CD 25 expression on B cell surface with autoimmunity. To the best of our knowledge, there is no study indicating relationship between CD25 expression on B cells and autoimmunity. To conclude; this study demonstrated association with increased autoimmune cytopenia in CLL patients with negative $\mathrm{CD} 25$ expression for the first time in literature. This finding may guide clinicians in the clinical follow-up of CLL patients especially those with reduced CD25 expression. They should be monitored more carefully with the possibility of autoimmune cytopenia occurrence.

\section{REFERENCES}

1. Cheson BD, Bennett JM, Grever M, et al. National Cancer Institute-sponsored Working Group guidelines for chronic lymphocytic leukemia: revised guidelines for diagnosis and treatment. Blood 87: 4990-4997, 1996.

2. Rozman C, Montserrat E. Chronic lymphocytic leukemia. N Engl J Med 333: 1052-1057, 1995. Review. Erratum in: N Engl J Med 333: 1515, 1995.

3. Hallek M, Cheson BD, Catovsky D, et al. International Workshop on Chronic Lymphocytic Leukemia. Guidelines for the diagnosis and treatment of chronic lymphocytic leukemia: a report from the International Workshop on Chronic Lymphocytic Leukemia updating the National Cancer Institute-Working Group 1996 guidelines. Blood 111: 5446-5456, 2008. Erratum in: Blood 112: 5259, 2008.

4. Hodgson K, Ferrer G, Montserrat E, Moreno C. Chronic lymphocytic leukemia and autoimmunity: a systematic review. Haematologica 96: 752-761, 2011.

5. Visco C, Rodeghiero F. Immune thrombocytopenia in lymphoproliferative disorders. Hematol Oncol Clin North Am 23: 1261-1274, 2009.

6. Zent CS, Kay NE. Autoimmune complications in chronic lymphocytic leukaemia (CLL). Best Pract Res Clin Haematol 23: 47-59, 2010.

7. Zent CS, Ding W, Reinalda MS, et al. Autoimmune cytopenia in chronic lymphocytic leukemia/small lymphocytic lymphoma: changes in clinical presentation and prognosis. Leuk Lymphoma 50: 1261-1268, 2009.

8. Shvidel L, Braester A, Bairey O, et al; Israeli CLL Study Group. Cell surface expression of CD25 antigen (surface IL-2 receptor $\alpha$-chain) is not a prognostic marker in chronic lymphocytic leukemia: results of a retrospective study of 281 patients. Ann Hematol 91: 1597-602, 2012.

9. Tefferi A, Bartholmai BJ, Witzig TE, et al. Clinical correlations of immunophenotypic variations and the presence of trisomy 12 in B-cell chronic lymphocytic leukemia. Cancer Genet Cytogenet 95: 173-177, 1997.

10. Nakase K, Kita K, Miwa H, et al. Clinical and prognostic significance of cytokine receptor expression in adult acute lymphoblastic leukemia: interleukin-2 receptor alpha-chain predicts a poor prognosis. Leukemia 21: 326-332, 2007.

11. Oki $\mathrm{Y}$, Kato $\mathrm{H}$, Matsuo $\mathrm{K}$, et al. Prognostic value of serum soluble interleukin-2 receptor level in patients with diffuse large B cell lymphoma, treated with CHOP- or RCHOP-based therapy. Leuk Lymphoma 49: 1345-1351, 2008.

12. Hjalmar V, Hast R, Kimby E. Cell surface expression of CD25, CD54, and CD95 on B- and T-cells in chronic lymphocytic leukaemia in relation to trisomy 12 , atypical morphology and clinical course. Eur J Haematol 68: 127-134, 2002.

13. Capello D, Zucchetto A, Degan M, et al. Immunophenotypic characterization of IgVH3-72 B-cell chronic lymphocytic leukaemia (B-CLL). Leuk Res 30: 1197-1199, 2006.

14. Zucchetto A, Sonego P, Degan M, et al. Signature of B-CLL with different prognosis by Shrunken centroids of surface antigen expression profiling. J Cell Physiol 204: 113-123, 2005.

15. Stewart CC, Stewart SJ. Immunophenotyping. Curr Protoc Cytom 2001: Chapter 6:Unit 6.2.

16. Oscier D, Dearden C, Eren E, et al; British Committee for Standards in Haematology. Guidelines on the diagnosis, investigation and management of chronic lymphocytic leukaemia. Br J Haematol 159: 541-564, 2012. 
17. Moreau EJ, Matutes E, A'Hern RP, et al. Improvement of the chronic lymphocytic leukemia scoring system with the monoclonal antibody SN8 (CD79b). Am J Clin Pathol 108: 378382, 1997.

18. Bonelli M, Savitskaya A, Steiner CW, Rath E, Smolen JS, Scheinecker $\mathrm{C}$. Phenotypic and functional analysis of CD4+ CD25- Foxp3+ T cells in patients with systemic lupus erythematosus. J Immunol 182: 1689-1695, 2009.

19. Yang HX, Zhang W, Zhao LD, et al. Are CD4+CD25-Foxp3+ cells in untreated new-onset lupus patients regulatory $T$ cells? Arthritis Res Ther 11: R153, 2009.

20. Fransson $\mathrm{M}$, Burman $\mathrm{J}$, Lindqvist $\mathrm{C}$, et al. $\mathrm{T}$ regulatory cells lacking CD25 are increased in MS during relapse. Autoimmunity 43: 590-597, 2010.

21. de Paz B, Prado C, Alperi-López M, et al. Effects of glucocorticoid treatment on $\mathrm{CD}_{25} \mathrm{FOXP3}^{+}$population and cytokineproducing cells in rheumatoid arthritis. Rheumatology (Oxford) 51: 1198-207, 2012.

22. Zhang $B$, Zhang $X$, Tang FL, et al. Clinical significance of increased CD4+CD25-Foxp3+ $T$ cells in patients with newonset systemic lupus erythematosus. Ann Rheum Dis 67: 1037-1040, 2008.

23. Strieder TG, Drexhage HA, Lam-Tse WK, et al. A reduced IL2R (CD25) expression level in first and second degree female relatives of autoimmune thyroid disease patients. A sign of a poor capability to preserve tolerance? Autoimmunity 39 : 93-98, 2006.

24. Atkinson TP. Immune deficiency and autoimmunity. Curr Opin Rheumatol 24: 515-521, 2012.

25. Mqadmi A, Zheng X, Yazdanbakhsh K. CD4+CD25+ regulatory $T$ cells control induction of autoimmune hemolytic anemia. Blood 105: 3746-3748, 2005.

\section{Correspondence:}

Dr. Hacer Berna Afacan ÖZTÜRK

Saglik Bilimleri Üniversitesi

Tip Fakültesi

Diskapi Yildirim Beyazit Egitim ve Arastirma Hastanesi

Hematology Bolümü

Diskapi, ANKARA / TURKEY

Tel: $\quad(+90-549) 5995454$

Fax: (+90-312) 2562340

e-mail: bernaafacan@yahoo.com 